\title{
Activities of Anaplerotic Enzymes and Acetyl Coenzyme A Carboxylase in Biotin-deficient Bacillus megaterium
}

\author{
By R. M. AL-SSUM AND P. J. WHITE \\ Department of Microbiology, The University, Western Bank, Sheffield Sı $2 T N$
}

(Received 20 December 1976)

INTRODUCTION

Morphological deformity of Bacillus megaterium NCIB758 I grown at $37^{\circ} \mathrm{C}$ in a minimal chemically defined medium could be prevented by addition of either biotin, aspartate or acetate (Al-ssum \& White, 1977). The only carbon source in the minimal medium was glycerol or glucose, and the metabolism of either of these two substrates requires an adequate conversion of $\mathrm{C}_{3}$ compounds [e.g. pyruvate or phosphoenolpyruvate (PEP)] to $\mathrm{C}_{4}$ compounds anaplerotically, to replace citric acid cycle intermediates that are withdrawn for biosynthesis. Such conversion occurs in bacteria mainly by the action of a $\mathrm{CO}_{2}$-fixing enzyme, either the biotin-dependent pyruvate carboxylase, or the biotinindependent PEP carboxylase; generally, organisms have one or other (not both) of these enzymes (Kornberg, I 966). Anaplerotic synthesis of $\mathrm{C}_{4}$ compounds could also occur independently of $\mathrm{CO}_{2}$-fixing enzymes by the operation of the glyoxylate cycle. Another biotinrequiring enzyme is acetyl coenzyme A carboxylase, which catalyses the ATP-dependent carboxylation of acetyl-CoA to yield malonyl-CoA (see review by Vagelos, I 964). In biotindeficient organisms, the activity of this enzyme might be lowered, so that synthesis of fatty acids (via malonyl-CoA) might be impaired.

The nutritional evidence suggests that in B. megaterium $\mathrm{NCIB} 758 \mathrm{I}$ an active pyruvate carboxylase is necessary unless a source of $\mathrm{C}_{4}$ compounds (e.g. aspartate) is available or unless the glyoxylate cycle is functioning. In this paper, activities of three anaplerotic enzymes and of acetyl-CoA carboxylase and malic enzyme are compared in organisms grown with and without biotin. A preliminary report of some of these results has been made (Al-ssum \& White, 1974).

\section{METHODS}

Organism and growth conditions. Bacillus megaterium NCIB758 I was maintained on nutrient agar slopes at $37^{\circ} \mathrm{C}$, subcultured monthly and stored at $2{ }^{\circ} \mathrm{C}$. Batches of $500 \mathrm{ml}$ medium AI (White, 1972), with or without biotin ( $10 \mu \mathrm{g} \mathrm{I}^{-1}$ ) or other supplements, in 21 flasks were inoculated with $\mathrm{r} \cdot 0 \mathrm{ml}$ of a suspension of organisms from nutrient agar (about $0.04 \mathrm{mg}$ dry wt bacteria $\mathrm{ml}^{-1}$ ) and incubated with shaking (200 gyrations $\mathrm{min}^{-1}$ ) at $37^{\circ} \mathrm{C}$ or $30^{\circ} \mathrm{C}$ for I 2 to $15 \mathrm{~h}$. Early in the exponential growth phase [EEL colorimeter reading with neutral density filter (no. I.O) about I.0; about $0.5 \mathrm{mg}$ dry wt organisms $\mathrm{ml}^{-1}$ ], the bacteria were harvested by centrifuging at $5000 \mathrm{~g}$ and washed in $0.05 \mathrm{M}$-Tris/ $\mathrm{HCl}$ buffer, $\mathrm{pH} 7 \cdot 4$. At later stages of growth $B$. megaterium NCIB758I was much less susceptible to the action of lysozyme (see below).

Preparation of extracts. (i) Organisms were suspended in $0 \cdot 1 \mathrm{M}$-Tris/ $\mathrm{HCl}$ buffer, $\mathrm{pH} 7 \cdot 8$, and sonicated in an MSE I $25 \mathrm{~W}$ apparatus for a total of $3 \mathrm{~min}$, with cooling at $2{ }^{\circ} \mathrm{C}$ for I min between each I min burst of sonication. Supernatant liquid was kept after centrifuging at $17000 \mathrm{~g}$ at $2{ }^{\circ} \mathrm{C}$. 
(ii) Organisms in the same buffer were put through the pressure cell of Milner, Lawrence \& French (1950) at $2{ }^{\circ} \mathrm{C}$ and $\mathrm{I} \cdot 4 \times 10^{8} \mathrm{~Pa}$. Supernatant liquid was kept after centrifuging at $12000 \mathrm{~g}$ at $2{ }^{\circ} \mathrm{C}$.

(iii) Bacterial suspension (about $5 \mathrm{mg}$ dry wt $\mathrm{ml}^{-1}$ ) containing $\mathrm{I} 20 \mu \mathrm{g}$ lysozyme $\mathrm{ml}^{-1}$, in the desired enzymic assay system buffer (O.I M) at the $\mathrm{pH}$ value used for the subsequent enzyme assay, was incubated at $30^{\circ} \mathrm{C}$ for $30 \mathrm{~min}$. To obtain a homogeneous extract, the viscous lysate was sonicated for $30 \mathrm{~s}$ (as above) at $2{ }^{\circ} \mathrm{C}$ and centrifuged at $17000 \mathrm{~g}$.

Assays. Pyruvate carboxylase (EC 6.4 I . I) was assayed by a modification of the method of Sundaram, Cazzulo \& Kornberg (1969) in which $0.5 \mu \mathrm{mol}$ acetyl-CoA was used and citrate synthase (I unit) replaced malate dehydrogenase and NADH. The reaction was started by addition of extract (50 $\mu \mathrm{l}$; about $0.25 \mathrm{mg}$ protein), and the system was incubated at $30^{\circ} \mathrm{C}$ for Io to I $5 \mathrm{~min}$. The reaction was stopped by adding $\mathrm{I} \cdot 5 \mathrm{ml}$ ethanol. Samples were removed to scintillation vials, acidified, dried and counted in a fluid containing: Triton X-100, $333 \mathrm{ml}$; xylene, $667 \mathrm{ml}$; 2,5-diphenyloxazole, $5 \mathrm{~g}$; 1,4-di-2(5-phenyloxazolyl)benzene, $0.5 \mathrm{~g}$.

Phosphoenolpyruvate carboxylase (EC 4.I.I.3I) was assayed similarly except that in the assay system the $\mathrm{pH}$ value was $8 \cdot 6$, PEP was substituted for pyruvate, and ATP and $\mathrm{KCl}$ were omitted.

Acetyl-CoA carboxylase (EC 6.4.I.2) was assayed by the method of Alberts \& Vagelos (I968).

Isocitrate lyase (EC 4.I.3.I) was assayed by the method of Dixon \& Kornberg (1959).

Malic enzyme (EC I.I.I.38 with $\mathrm{NAD}^{+}$; EC I.I.I.40 with NADP ${ }^{+}$) was assayed manometrically at $\mathrm{pH} 7.4$ (Scrutton, 197I). After equilibration at $30^{\circ} \mathrm{C}$ the reaction was started by tipping the enzyme (about $5 \mathrm{mg}$ protein) from the side arm. After $15 \mathrm{~min}$, I ml

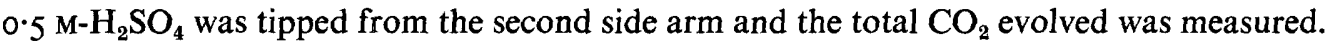

Protein was assayed by the method of Lowry et al. (195I) with bovine serum albumin as standard.

Chemicals. Acetyl-CoA was prepared from coenzyme A and acetic anhydride by a method similar to that used for the synthesis of succinyl-CoA (Simon \& Shemin, 1953). Citrate synthase and malate dehydrogenase were from Boehringer; lysozyme (egg white) from $\mathrm{BDH}$; and $\mathrm{NaH}^{14} \mathrm{CO}_{3}$ from The Radiochemical Centre, Amersham.

\section{RESULTS AND DISCUSSION}

Pyruvate carboxylase was measured in extracts of $B$. megaterium by fixing ${ }^{14} \mathrm{CO}_{2}$ from bicarbonate to pyruvate - this produced oxaloacetate which, with acetyl-CoA and citrate synthase, was converted to citrate before counting the radioactivity. A gentle preparation of extracts (i.e. by lysozyme digestion of the wall) was essential to obtain an active enzyme; extracts prepared by sonication or the pressure cell did not incorporate ${ }^{14} \mathrm{CO}_{2}$, which suggests that the enzyme was damaged by the last two methods of extraction. Spectrophotometric assays were unsuccessful owing to the presence of NADH oxidase and malic enzyme, which interfered with the method of Utter \& Keech (1963), and deacylating activity, which interfered with the method of Martin \& Denton (1970).

High activity of pyruvate carboxylase was found only in organisms grown at $30{ }^{\circ} \mathrm{C}$ with or without biotin, or at $37^{\circ} \mathrm{C}$ with biotin (Table I). Enzyme activity was decreased by omission of sodium pyruvate ( $13 \%$ activity), ATP ( $30 \%$ activity) or acetyl-CoA ( $3 \%$ activity) from the assay system. The highest measured activities of pyruvate carboxylase were rather lower than might be expected from the observed rate of growth [about $30 \mathrm{nmol} \mathrm{min}-1$ (mg protein $)^{-1}$ ] though some enzyme may well be lost during the most gentle extraction. 
Table I. Enzymic activities in extracts of B. megaterium NCIB758I

after growth at $37^{\circ} \mathrm{C}$ in medium $\mathrm{AI}$

Cultures were grown and extracts were prepared and assayed for enzymes as described in Methods. The three carboxylases were assayed in protoplast lysates; activities are expressed as $\mathrm{nmol}^{14} \mathrm{CO}_{2}$ fixed $\mathrm{min}^{-1}\left(\mathrm{mg}^{2}\right.$ protein $)^{-1}$. Malic enzyme was assayed in press extracts; activities are expressed as $\mathrm{nmol} \mathrm{CO}_{2}$ evolved min ${ }^{-1}$

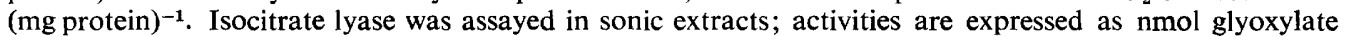
formed $\mathrm{min}^{-1}$ (mg protein) ${ }^{-1}$.

Addition to medium

Enzyme

Pyruvate carboxylase

PEP carboxylase

Acetyl-CoA carboxylase

Isocitrate lyase

Malic enzyme, NAD ${ }^{+}$cofactor

Malic enzyme, NADP ${ }^{+}$cofactor

\begin{tabular}{|c|c|c|c|}
\hline \multicolumn{4}{|c|}{ Addition to medium } \\
\hline No addition & $\begin{array}{c}\text { Biotin } \\
\left(10 \mu \mathrm{g} 1^{-1}\right)\end{array}$ & $\begin{array}{l}\text { L-Aspartate } \\
\left(100 \mathrm{mg} \mathrm{l}^{-1}\right)\end{array}$ & $\begin{array}{l}{ }^{*} \text { Sodium } \\
\text { acetate. } 3 \mathrm{H}_{2} \mathrm{O} \\
\left(0.5 \mathrm{~g} \mathrm{l}^{-1}\right)\end{array}$ \\
\hline $8 \cdot 7(22) \dagger$ & $25(24) \dagger$ & $7 \cdot 8$ & $5 \cdot 7$ \\
\hline $\mathrm{I} \cdot \mathrm{I}$ & $I \cdot 6$ & $\mathrm{I} \cdot 4$ & $1 \cdot 8$ \\
\hline $1 \cdot 7$ & $7 \cdot 8$ & $2 \cdot 0$ & 3.9 \\
\hline $3 \cdot 2$ & 0.9 & 0.7 & 16 \\
\hline I I & 13 & 15 & I6 \\
\hline I4 & 23 & 26 & 22 \\
\hline
\end{tabular}

* Only $0.25 \%(w / v)$ glycerol in medium.

$\dagger$ Activities in organisms grown at $30^{\circ} \mathrm{C}$.

If biotin was absent from the growth medium at $37^{\circ} \mathrm{C}$ enzymic activity decreased to onethird, which might be a cause of the slower growth and deformity of the organisms. Neither acetate nor aspartate, which allowed normal growth at $37^{\circ} \mathrm{C}$ without biotin, increased the activity of pyruvate carboxylase (Table I), and so the effects of these two compounds are not due to biotin present as an impurity. Indeed, aspartate inhibited pyruvate carboxylase when added to the assay system; $0.6 \mathrm{~mm}$-aspartate caused $50 \%$ inhibition. Cazzulo, Sundaram \& Kornberg (1970) found that aspartate inhibited formation of active pyruvate carboxylase from biotin and apoenzyme.

Phosphoenolpyruvate carboxylase. Only low activity of this enzyme was found in extracts (Table I), even though the same extracts contained pyruvate carboxylase. Since this latter labile enzyme was detected, it seems unlikely that PEP carboxylase had been present in the organisms but lost during extraction. Furthermore, when the assay system was tested with an extract of Pseudomonas AMI grown on methanol (given by $\mathrm{Mr} \mathrm{A}$. A. Hancock of this Department), a PEP carboxylase activity of $45 \mathrm{nmol} \mathrm{min}^{-1}$ (mg protein $)^{-1}$ was found.

Acetyl-CoA carboxylase. Organisms grown at $37^{\circ} \mathrm{C}$ without biotin had less acetyl-CoA carboxylase activity than those grown with biotin (Table $\mathrm{I}$ ). The presence of acetate or aspartate in the medium without biotin at $37^{\circ} \mathrm{C}$ caused a slight increase in enzymic activity, possibly by sparing the need for biotin as a cofactor of pyruvate carboxylase. Aspartate in the assay system was inhibitory; $0.5 \mathrm{~mm}$-aspartate caused $50 \%$ inhibition.

The activity of acetyl-CoA carboxylase in organisms grown at $37^{\circ} \mathrm{C}$ with aspartate but without biotin was considerably lower than might be expected from the observed rate of

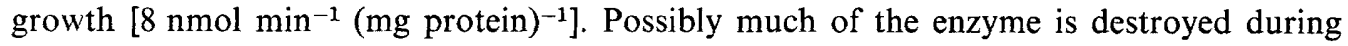
extraction, but the inhibition by aspartate suggests that this enzyme need not function if aspartate is available, when malonate might perhaps be formed by a different route. In bush bean roots, oxaloacetate (from aspartate) is decarboxylated by an oxidative system to yield malonate (Shannon, de Villes \& Lew, 1963). The bacterial enzymes, aspartate I-decarboxylase (see review by Meister, I 965), $\beta$-alanine aminotransferase (Hayaishi \& Nishizuka, 1962) and malonic semialdehyde dehydrogenase (Nakamura \& Bernheim, I96I) acting in sequence also might provide a route from aspartate to malonate.

Isocitrate lyase (glyoxylate cycle). The effectiveness of acetate in allowing normal growth 
without biotin at $37^{\circ} \mathrm{C}$ was probably a result of inducing the glyoxylate cycle (Table I). Isocitrate lyase was found at relatively high activity only after growth with acetate (plus glycerol). The products of the enzyme reaction were identified as glyoxylate phenylhydrazones (two isomers) by their absorption at $325 \mathrm{~nm}$ and by the chromatographic properties of the 2,4-dinitrophenylhydrazones.

Malic enzyme. This enzyme was assayed because it might be present in biotin-deficient organisms and able to convert pyruvate to malate rather than catalysing the reverse reaction. Activity of malic enzyme was highest under growth conditions where the supply of $\mathrm{C}_{4}$ compounds was presumably adequate (Table I). This finding supports the view that the role of malic enzyme is to provide a supply of NADPH and to regulate the intracellular concentration of $\mathrm{C}_{4}$ compounds (cf. Krulwich, Sharon \& Perrin, 1976).

We are grateful to Dr A. Salem for help during the early stages of this work. R.M.A. received financial support from Riyad University, Saudi Arabia.

\section{REFERENCES}

Alberts, A. W. \& VAgelos, P. R. (1968). Acetyl CoA carboxylase. 1. Requirement for two protein fractions. Proceedings of the National Academy of Sciences of the United States of America 59, 56I-568.

Al-ssum, R. M. \& WhITE, P. J. (1974). Biotin deficiency in Bacillus megaterium. Proceedings of the Society for General Microbiology 1, 69-70.

Al-SSUM, R. M. \& WHITE, P. J. (1977). Effects of biotin-deficiency on growth, morphology and sporulation in Bacillus megaterium NCIB758I. Journal of General Microbiology 99, 343-35I.

Cazzulo, J. J., Sundaram, T. K. \& KornberG, H. L. (1970). Mechanism of pyruvate carboxylase formation from the apo-enzyme and biotin in a thermophilic bacillus. Nature, London 227, I 103-I 105.

Dixon, G. H. \& Kornberg, H. L. (1959). Assay methods for key enzymes of the glyoxylate cycle. Biochemical Journal 72, $3 \mathrm{P}$.

HAYAIShI, O. \& NishizUKA, Y. (1962). $\beta$-Alanine- $\alpha$-alanine transaminase (Pseudomonas). Methods in Enzymology 5, 698-702.

KornBerG, H. L. (1966). Anaplerotic sequences and their role in metabolism. In Essays in Biochemistry, vol. 2, pp. I-3I. Edited by P. N. Campbell and G. D. Greville. London and New York: Academic Press.

Krulwich, T. A., Sharon, B. I. \& Perrin, L. S. (1976). Natural paucity of anaplerotic enzymes: basis for dependence of Arthrobacier pyridinolis on L-malate for growth. Journal of Bacteriology 127, 179-183.

Lowry, O. H., Rosebrough, N. J., FArR, A. L. \& Randall, R. J. (I95I). Protein measurement with the Folin phenol reagent. Journal of Biological Chemistry 193, 265-275.

Martin, B. R. \& Denton, R. M. (1970). The intracellular localization of enzymes in white-adipose-tissue fat-cells and permeability properties of fat cell mitochondria. Transfer of acetyl units and reducing power between mitochondria and cytoplasm. Biochemical Journal 117, 861-877.

Meister, A. (1965). Biochemistry of the Amino Acids, and edn, p. 335. New York and London: Academic Press.

Milner, H. W., Lawrence, N. S. \& French, C. S. (I950). Colloidal dispersion of chloroplast material. Science III, 633-634.

Nakamura, K. \& Bernheim, F. (I96I). Studies on malonic semialdehyde dehydrogenase from Pseudomonas aeruginosa. Biochimica et biophysica acta 50, 147-I 52.

SCrutton, M. C. (I971). Assays of enzymes of $\mathrm{CO}_{2}$ metabolism. Methods in Microbiology 6A, 479-54I.

Shannon, L. M., de Vellis, J. \& Lew, J. Y. (1963). Malonic acid biosynthesis in bush bean roots. II. Purification and properties of enzyme catalyzing oxidative decarboxylation of oxaloacetate. Plant Physiology, Lancaster 38, 69I-697.

Simon, E. J. \& Shemin, D. (1953). The preparation of $S$-succinyl coenzyme A. Journal of the American Chemical Society 75, 2520.

Sundaram, T. K., Cazzulo, J. J. \& Kornberg, H. L. (1969). Anaplerotic $\mathrm{CO}_{2}$ fixation in mesophilic and thermophilic bacilli. Biochimica et biophysica acta $\mathbf{1 9 2 , 3 5 5 - 3 5 7 .}$

Utter, M. F. \& KeECH, D. B. (I963). Pyruvate carboxylase. I. Nature of the reaction. Journal of Biological Chemistry 238, 2603-2608.

Vagelos, P. R. (1964). Lipid metabolism. Annual Review of Biochemistry 33, 139-1 72.

White, P. J. (1972). The nutrition of Bacillus megaterium and Bacillus cereus. Journal of General Microbiology 7I, 505-5I4. 